logos_i_ethos_2013_2_(35), s. 219-234

\title{
Krzysztof Stachewicz
}

\section{O filozofii chrześcijańskiej}

Kilka uwag z perspektywy historycznej i futurologicznej

\author{
Ważne w filozofii jest dla nas nie to, że jest \\ chrześcijańska, \\ lecz że jest prawdziwa. \\ A jednak aby była prawdziwa, \\ niezastąpiona jest dla niej pomoc \\ chrześcijańskiej wiary i natchnienia.
}

(Jacques Maritain)

My, mieszkańcy Zachodu, wszyscy pozostaje-

my chrześcijanami.

(Karl Jaspers)
Krzysztof Stachewicz - prof. dr hab., filozof i etyk, kierownik Zakładu Filozofii Chrześcijańskiej UAM w Poznaniu, autor 5 książek i wielu artykułów z zakresu etyki, filozofii człowieka, aksjologii i filozofii zła. Ostatnio wydał: Milczenie wobec dobra $i$ zła. W strone etyki sygetycznej i apofatycznej (Poznań 2012) oraz Żyć i rozumieć. Szkice o człowieku i moralności (Poznań 2013).

\section{Filozofia chrześcijańska - prelu- dium historyczne}

Spotkanie chrześcijaństwa ze światem pogańskiej filozofii miało bardzo różny przebieg. Wśród myślicieli wczesnochrześcijańskich wyraźnie wykrystalizowały się dwie opcje: antyfilozoficzna reprezentowana przez Tertuliana oraz profilozoficzna, której patronował św. Justyn Męczennik. W tym sporze o potrzebę filozofii w ramach religii chrześcijańskiej ujawnia się źródłowo kwestia istnienia filozofii chrześcijańskiej i jej ewentualnego charakteru. Czy głoszeniu kerygmy potrzebna jest filozofia? Czy myślenie nad pierwszymi zasadami, nad bytem i byciem, nad sensem, Całością jest w jakikolwiek sposób potrzebne chrześcijaninowi, który zaufał Jezusowi, osobowej Prawdzie? Czy teoria filozofii i soteryzm religii mają jakieś punkty wspólne? Czy szlaki życiowe, myślowe filozofii i chrześcijaństwa gdzieś się przecinają? A może wzajemnie się 
potrzebują? Te pytania wprost i nie wprost pojawiają się w wielu miejscach pism ojców Kościoła i pierwszych myślicieli chrześcijańskich czasów patrystycznych.

Już w tym pierwszym okresie wyraźnie pojawiają się przynajmniej dwa podstawowe sensy i rozumienia filozofii chrześcijańskiej. Pierwszy, jak się wydaje dominujący, to rozumienie filozofii jako sposobu życia. Nawiązywało to do rozumienia starożytnych myślicieli pogańskich, dla których moment ascetyczny, egzystencjalny rozważań filozoficznych był nierzadko pierwszoplanowy. Wskazują na to w swych znakomitych opracowaniach Pierre Hadot ${ }^{1}$ czy Juliusz Domański ${ }^{2}$, widząc w starożytnym filozofowaniu sposób kształtowania życia, ćwiczenia duchowe, uczenie się sztuki życia. Przyjęcie określonej filozofii oznaczało wszak u samego Platona „nawrócenie”, zmianę sposobu życia ${ }^{3}$. Kiedy św. Jan Chryzo-

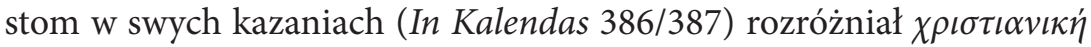

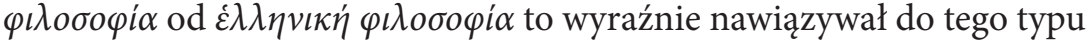
rozumienia filozofii. Chrześcijaństwo dla św. Grzegorza z Nyssy to właśnie życie filozoficzne ${ }^{4}$. Filozofia chrześcijańska zatem to chrześcijańskie rozumienie świata, doświadczanie rzeczywistości, a przede wszystkim chrześcijański sposób życia. Także w średniowiecznej teologii monastycznej odnajdujemy takie rozumienie filozofii. Klasztor stanowił dla mnichów chrześcijańską szkołę filozofii, wręcz spekulatywną filozofię chrześcijańską (jest to wyraźne w XII i XIII wieku, a przykładem pisma Wilhelma z Newbury), a filozofia służyła życiu ascetycznemu, zakonnemu i w nich się niejako ujawniała, uobecniała. Dla Erazma z Rotterdamu filozofia Chrystusowa polegała na szeregu zaleceń i rad typu moralnego, które pozwalają uczniowi Jezusa realizować w swym życiu ideał etyczny. Filozofia chrześcijańska ma wyłącznie biblijną, a nie dyskursywną, postać.

Por. P. Hadot, Czym jest filozofia starożytna?, tłum. P. Domański, Warszawa 2000; tenże, Filozofia jako ćwiczenie duchowe, tłum. P. Domański 2003.

Por. J. Domański, Metamorfozy pojęcia filozofii, Warszawa 1996.

Por. W. Jaeger, Wczesne chrześcijaństwo i grecka paideia, tłum. K. Bielawski, Bydgoszcz 1997, s. 31.

Por. tamże, s. 101. 
Joseph Ratzinger zwrócił uwagę, że w najstarszych przedstawieniach Chrystusa w sztuce wczesnochrześcijańskiej jest On pasterzem oraz filozofem ${ }^{5}$. Ludzkie poszukiwanie filozofa, który da zadawalającą odpowiedź na pytanie o śmierć, zdawało się wszak odnajdywać swój kres w Jezusie, który zwyciężył śmierć i wskazał drogę życia. Czytamy w encyklice Spe Salvi: „Na ogół filozofia nie była wówczas rozumiana jako trudna dyscyplina akademicka, jak przedstawia się ją dzisiaj. Filozof był raczej tym, który potrafi nauczać podstawowej sztuki: sztuki bycia prawym człowiekiem, sztuki życia i umierania” (nr 6). Przesłanie chrześcijaństwa jawiło się zatem jako szczyt filozoficznej mądrości, jako czysta filozofia, przemieniająca życie i udzielająca odpowiedzi na pytanie o człowieczą śmiertelność. Takie przesłanie starożytnej sztuki chrześcijańskiej było żywe także w późniejszych pismach patrystycznych. Chrystus jako prawdziwy filozof, a chrześcijaństwo jako szczyt czystej filozofii, prawdziwej filozofii (philosophia verissima św. Augustyna), uczącej życia i umierania - oto pierwszy, praktyczny, sens określenia filozofia chrześcijańska.

Drugie rozumienie filozofii w świecie wczesnochrześcijańskim to wskazywanie na jej teoretyczną doniosłość jako drogi do prawdy. Filozofia pogańska szukała tej prawdy i ją odkrywała, tym samym schodząc się z przyszłą religią chrześcijan. Pisał o tym św. Justyn: „Cokolwiek prawdziwego zostało powiedziane, stało się własnością chrześcijan”. Chrześcijaństwo dla Justyna stanowiło wypełnienie czystej filozofii, wręcz filozofię jako taką. Chrześcijańskie nauczanie, przesłanie to właśnie filozofia. Piotr Chojnacki, nie bez racji, proponuje w tym kontekście inne określenie: „filozofia chrześcijaństwa” wyraźnie odróżnione od „filozofii chrześcijańskiej”7.

Por. J. Grzeszczak, Christus philosophicus jako aktualne przesłanie sztuki wczesnochrześcijańskiej. Uwagi na marginesie wykładu kard. Josepha Ratzingera Wiara, filozofia, teologia, „Filozofia Chrześcijańska” 6, 2009, s. 31-45.

Cyt. za: Ph. Böhner, E. Gilson, Historia filozofii chrześcijańskiej, Warszawa 1962, s. 33.

Por. P. Chojnacki, Wybór pism, red. M. Szyszkowska, C. Tarnogórski, Warszawa 1987, s. 147: „Filozofia chrześcijaństwa obejmuje pewien zespół zdań więcej lub mniej dokładnie usystematyzowanych, mających na celu wyjaśnienie, względnie udostępnienie dla umysłu ludzkiego tez pochodzących z Objawienia Bożego i stąd przerastających zdolności poznawcze ludzkie. Częściami tak pojętej filozofii chrześcijaństwa są apologetyka i teologia spekulatywna”. Natomiast 
Spotkanie autonomicznej filozofii z chrześcijaństwem - nastąpiło to twórczo po raz pierwszy w osobach św. Klemensa Aleksandryjskiego i Orygenesa ${ }^{8}$ - dało zatem filozofię chrześcijańską (X. Tilliette). Widać to wyraźnie w myśli św. Tomasza z Akwinu, który dokonał rozdzielenia porządku poznawczego filozofii i teologii. Obie dyscypliny zajmują się całością świata, rzeczywistością w świetle ostatecznych zasad. Przedmiotem formalnym teologii jest Objawienie, prawdy wiary, a w filozofii jest to naturalne, czyli zmysłowo-umysłowe poznanie. Metodą teologii jest zatem wiara, a filozofii rozum. Pytanie o możliwość istnienia filozofii chrześcijańskiej stawało w takiej optyce w swej pełnej doniosłości. We wcześniej stworzonym paradygmacie augustyńskim związek myślenia filozoficznego i teologicznego był wręcz organiczny, stąd mówienie o filozofii chrześcijańskiej zdawało się całkowicie naturalne, choć rozszerzające do granic rozumienie filozofii jako takiej. W paradygmacie tomistycznym zostało sproblematyzowane.

Wszystkie powyższe uwagi dotyczą generalnie chrześcijańskiego Zachodu. Na Wschodzie bowiem myślenie chrześcijańskie funkcjonowało poza i poniekąd ponad rozdziałem filozofia - teologia, tworząc organiczną całość w postaci myśli religijnej. Jest to widoczne także we współczesnej myśli pozostającej pod wpływem kultury prawosławnej. Na Zachodzie, z kolei, szesnastowieczna Reformacja rozerwała związek filozofii z teologią i piórem Lutra czy Kalwina, nawiązując do ducha tertuliańskiego, przekreślała doniosłość jakichkolwiek badań filozoficznych na terenie chrześcijaństwa. Dwudziestowiecznym przykładem takiego podejścia jest myśl Karla Bartha, choć kontrprzykłady znajdziemy również w myśli protestanckiej (kalwiński pastor Alvin Plantinga to tylko jeden z nich).

W dwudziestowiecznej historii filozofii rozgrywa się, głośny swego czasu, spór o istnienie filozofii chrześcijańskiej, o jej faktyczność, historyczne zaistnienie. Spór został zapoczątkowany przez francuskiego

w odniesieniu do filozofii chrześcijańskiej pisze: „Pod nazwą filozofii chrześcijańskiej rozumie się bowiem interpretację racjonalną danych, która się różni od innych interpretacji, również racjonalnych, tylko sposobem zapatrywania na Objawienie, zaliczając je do danych, gdy inne systemy tego nie czynią" (s. 156).

Por. W. Jaeger, Wczesne chrześcijaństwo..., dz. cyt., s. 59nn. 
historyka Emila Brehiera, który postawił w 1927 roku tezę, że chrześcijaństwo nie wywarło żadnego znaczącego wpływu na filozofię starożytną, powielając i repetując w średniowieczu wątki platońskie i arystotelesowskie. Nie było, nie ma i nie będzie filozofii chrześcijańskiej, tak jak nie było, nie ma i nie będzie chrześcijańskiej matematyki czy fizyki ${ }^{9}$. Zauważmy, że przeciwko istnieniu filozofii chrześcijańskiej wypowiadali się znakomici scholastycy, by wspomnieć Maurice’a de Wulfa, kardynała Dezyderiusza Merciera czy Fernanda Van Steenberghena. Pierwszy z nich pisał: „Nie ma katolickiej filozofii, podobnie jak nie ma katolickiej nauki. Są tylko filozofowie wierzący w pewne dogmaty, tak samo jak są chemicy lub lekarze, którzy są katolikami, protestantami, żydami" ${ }^{10}$. Istnieją filozofowie, którzy są chrześcijanami, ale nie istnieje coś takiego jak filozofia chrześcijańska, powtarzał Van Steenberghen. Neoscholastycy opowiadali się zdecydowanie po stronie filozofii rozumianej autonomicznie i odrzucali ich jakiekolwiek apologetyczne obciążenia. Przeciwko takiemu stawianiu sprawy oponował m.in. Etienne Gilson, twierdząc z punktu widzenia mediewisty, że filozofia chrześcijańska jest dziejowym faktem, jest fenomenem zapoczątkowanym w starożytności, rozwijającym się dynamicznie w średniowieczu i posiadającym wiele repetycji w czasach nowożytnych i współczesnych. Czytamy: „Nazywam więc filozofią chrześcijańską wszelką filozofię, która rozgraniczając formalnie obydwa porządki poznania, uznaje jednak objawienie chrześcijańskie za niezbędną pomoc dla rozumu"11. Filozof chrześcijański podejmuje trud rozumowego ugruntowania przynajmniej niektórych prawd religijnych, w które wierzy, zakłada poniekąd, że na drodze z gruntu niefilozoficznej można odkryć ważne prawdy stricte filozoficzne. Gilson przyznaje, że nie istnieje rozum chrześcijański, ale trzeba

\footnotetext{
E. Brehier, Histoire de la philosophie, Paris 1927; tenże, Ya-t-il une philosohie chrétienne, "Revue de la Mataphysique et de Morale" (1931), s. 1962.

10 Cyt. za: P. Chojnacki, Wybór pism, dz. cyt., s. 140.

11 E. Gilson, Duch filozofii średniowiecznej, tłum. J. Rybałt, Warszawa 1958, s. 38-39. Na s. 36-37 czytamy: „Treścią chrześcijańskiej filozofii jest zatem zespół prawd rozumowych - odkrytych, pogłębionych lub po prostu ocalonych dzięki pomocy, jaką rozum znalazł w objawieniu”.
} 
przyjąć chrześcijańską działalność rozumu ${ }^{12}$. Za istnieniem filozofii chrześcijańskiej opowiadał się też zdecydowanie Jacques Maritain, rozdzielając w niej aspekt obiektywny i subiektywny, co znajdzie później reperkusję w encyklice Jana Pawła II Fides et ratio. Maritain dostrzegał dwie implikacje problemu filozofii chrześcijańskiej. Pierwsza, materialna, oznacza, że określona filozofia rozwijała się w klimatach chrześcijańskich, a druga, formalna odnosi się do filozofii wewnętrznie zgodnej z wiarą chrześcijańską, korzystającej z prawd wiary, przez nie ożywia$n \mathrm{j}^{13}$. Maritain odróżniał naturę filozofii (czym jest sama w sobie) od jej stanu (historycznych uwarunkowań i konkretnych urzeczywistnień). Na poziomie natury filozofia nie może być chrześcijańska, natomiast na poziomie stanu faktycznego jest kształtowana w naszej kulturze przez chrześcijaństwo. W podobnym duchu podchodzi do sprawy Piotr Chojnacki, uważając, że filozofia rozumiana in abstracto, w oderwaniu od okoliczności, w których funkcjonuje, nie może być chrześcijańska. Natomiast rozważając historycznie ukształtowane systemy filozoficzne, wykrywamy niezaprzeczalne wpływy chrześcijaństwa na taki, a nie inny kształt myśli filozoficznej ${ }^{14}$. Objawienie chrześcijańskie stworzyło dla filozofii szereg problemów i zagadnień i otworzyło pole często radykalnie nowych i oryginalnych pytań. A zatem „o istnieniu i o sensie filozofii chrześcijańskiej nie można rozstrzygać, wychodząc z analizy konceptualnej, trzeba więc odwołać się do historii i trzymać się faktów"15.

$\mathrm{Z}$ innych pozycji metafilozoficznych przeciw istnieniu filozofii chrześcijańskiej opowiedział się Martin Heidegger, powiadając, że filozofia chrześcijańska to tyle, co hölzernes Eisen. Pisał we Wprowadzeniu do metafizyki: „ «Filozofia chrześcijańska» jest drewnianym żelazem

12 Por. tamże, s. 18.

13 Por. J. Maritain, O filozofii chrześcijańskiej, [w:] tenże, Pisma filozoficzne, tłum. J. Fenrychowa, Kraków 1988, s. 132.

14 P. Chojnacki, Wybór pism, dz. cyt., s. 149-150. „Otóż nie da się zaprzeczyć faktowi, że chrystianizm stał się pozytywnym przyczynkiem, odbijając się na sposobie filozofowania, bo pewne zagadnienia rozwinęły się jedynie dzięki wpływom chrystianizmu, który obok danych przyrodzonych stawia pewne zagadnienia, domagając się racjonalnego opracowania” (s. 150).

15 Tamże, s. 152. 
i nieporozumieniem. Istnieje co prawda krytyczne myślowe opracowanie świata doświadczanego po chrześcijańsku, tzn. wiary. Ale to teologia"16. Zresztą z punktu widzenia samego chrześcijaństwa istnienie filozofii chrześcijańskiej stanowiłoby dla Heideggera radykalne wypaczenie idei chrystianizmu. Z kolei Karl Jaspers widział w filozofii chrześcijańskiej filozofię myślącą zasadę jedności wiary i wiedzy, a augustynizm i tomizm to najlepsze jej historyczne wcielenia. W szerokim sensie filozofia europejska jawi się jako filozofia wyrastająca $\mathrm{z}$ ducha biblijnego: „Biblia i religia biblijna to podstawa naszego filozofowania, stały drogowskaz i źródło niezastąpionych treści. Na Zachodzie filozofuje się - czy się ktoś z tym zgodzi czy nie - zawsze z Biblią, nawet wtedy, gdy się ją zwalcza"17. Lew Szestow, z kolei, nawiązujący do Tertuliana widział w wiedzy filozoficznej efekt grzechu pierworodnego, a tym samym przeczył jakimkolwiek pozytywnym związkom chrześcijaństwa z filozofią. Powyższe uwagi nie są streszczeniem wielowiekowego sporu ożywionego w XX wieku przez Brehiera, lecz tylko wskazaniem na jego bieguny i niepewność samych historyków filozofii co do faktycznej eksplikacji dziejowej filozofii chrześcijańskiej oraz jej teoretycznej możliwości.

Nieco odmienną propozycją w sprawie filozofii chrześcijańskiej zdaje się być pomysł, z ducha augustyński, wysunięty przez Józefa Tischnera, a dotyczący budowania myślenia religijnego, które niejako wyprzedza teologię i stanowi jej fundament, początek, fundowany przez myślenie chrześcijańskie. Myślenie religijne stanowi syntezę prawdy i zbawienia, jako ostatecznego dobra człowieka. Pisał Tischner: „Wiara wydarza się w łonie myślenia i myślenie wydarza się w łonie wiary. Dlaczego wydarza się? Bo okazało się, że nie ma dla człowieka innej drogi do zbawienia niż poprzez prawdę - podstawowy ideał wszelkiego myślenia, i nie ma innej drogi do akceptacji godności myślenia niż poprzez uznanie, że myślenie jest dobrem człowieka - dobrem przybliżającym jego zbawienie" ${ }^{18}$. Tego typu podejście pozwala uniknąć - przyznać trzeba, że 
miejscami jałowej - dyskusji na temat możliwości uprawiania filozofii chrześcijańskiej przy zachowaniu zasady autonomii myślenia stricte filozoficznego. Nastawienie filozofii na prawdę spotyka się tu z ideą zbawienia, stanowiącą nerw religijnego przesłania chrześcijaństwa. Syntezą nie jest system filozofii chrześcijańskiej, lecz żywioł myślenia religijnego, które nie musi troszczyć się o zachowywanie autonomii, czystość i piętrowość metodologiczną etc., unikając eo ipso trudności i aporii. Zresztą w żywiole myślenia religijnego, nierespektującego dychotomii filozofia-teologia zdawała się przez wieki z powodzeniem funkcjonować myśl żydowska czy rosyjska.

\section{Zakres semantyczny pojęcia „filozofia chrześcijańska” oraz próba wstępnych uporządkowań i precyzacji}

Już powyższe uwagi pokazują rozległość znaczeniową terminu „filozofia chrześcijańska”. Konstatował to Gilson, pisząc: „niewiele jest określeń tak mglistych, tak trudnych do ścisłego zdefiniowania"19. Najbardziej fundamentalny zdaje się być jego sens egzystencjalny, praktyczny, odróżniony od stricte teoretycznego, o czym już była mowa wyżej. Ten drugi, z kolei, zdaje się obfitować w najrozmaitsze, nie zawsze ze sobą zgodne czy spójne, znaczenia. Zatrzymajmy się przy tym zagadnieniu nieco dłużej.

Wyjdźmy od pytania, jaka filozofia jest filozofią chrześcijańską, biorąc w nawias wątek „egzystencjalny” i skupiając się wyłącznie na esencjalnej stronie sporu o filozofię chrześcijańską. Problem postawmy na poziomie wstępnym, a odpowiedzi szukajmy na zasadzie prima vista. Filozofią chrześcijańską często nazywano i nazywa się filozofię, która spełnia przynajmniej jeden z następujących warunków: (1) posługuje się pojęciami i ideami wypracowanymi i odkrytymi w tradycji chrześcijańskiej (takimi jak osoba, stworzenie, godność, niezbywalne prawa człowieka, osobowy jedyny Bóg, wolna wola etc.) (2) jest uprawiana przez chrześcijan ${ }^{20}$,

${ }^{19}$ E. Gilson, Duch filozofii..., dz. cyt., s. 9 .

${ }^{20}$ Pisze bp Bronisław Dembowski: „wytworzył się zwyczaj, by filozofowanie dokonywane przez chrześcijan jako chrześcijan nazywać filozofią chrześcijańską" (B. Dembowski, O filozofii 
(3) jest uprawiana i nauczana w instytucjach kościelnych (tu i w punkcie 7 wobec tak rozumianej filozofii stosuje się często - do dziś jest to powszechne w myśli amerykańskiej - określenie „filozofia katolicka”), (4) przyjmuje na zasadzie inspiracji tezy pochodzące z Objawienia i następnie je uzasadnia (jej chrześcijańskość wiąże się zatem z kontekstem odkrycia, a nie uzasadnienia, by użyć idiomów wypracowanych przez Hansa Reichenbacha ${ }^{21}$, wierzyć jest tu przekuwane na wiedzieć, (5) głosi tezy niesprzeczne z prawdami chrześcijaństwa (kryterium negatywne), (6) powstała i rozwija się $\mathrm{w}$ klimatach stworzonych przez chrześcijaństwo (cała filozofia europejska od starożytności chrześcijańskiej), niezależnie nawet od znajomości prawd chrześcijaństwa; wpływ nie zakłada wszak jako swego warunku jego świadomości (7) posiada jakieś placet instytucji chrześcijańskich (jak tomizm w Aeterni Patris Leona XIII), (8) podejmuje tematy inspirowane przez dyskurs teologiczny lub stworzone przez dogmatykę religijną chrześcijaństwa, (9) otwiera na transcendencję, a przede wszystkim wskazuje na transcendencję jako kierunek zaangażowania człowieka, jego działania i spełniania się $e^{22}$ i (10) uznaje fundamentalne granice rozumu i otwiera świadomie filozoficzny system myślowy na poznanie z wiary („intellectus quaerens intellectum per fidem”- Maine de Biran). W zależności, który z warunków przyjmiemy jako „conditio sine qua non” będziemy stać na stanowisku określonej koncepcji filozofii chrześcijańskiej jako takiej i tym samym inaczej odpowiadać na pytanie o jej istnienie i historyczne wcielenia. Pytanie o kryteria demarkacji pomiędzy filozofią chrześcijańską a filozofią niechrześcijańską wiąże się z problemem jej tożsamości. Czy filozofia chrześcijańska i niechrześcijańska tworzą pole sprzeczności czy dopełnienia, dychotomii czy

chrześcijańskiej w Ameryce Pólnocnej, Warszawa1989, s. 13).

${ }_{21}$ Por. J.A. Kłoczowski, Filozofia chrześcijańska? Dyskusja w kontekście encykliki „Fides et ratio”, [w:] Polska filozofia wobec „Fides et ratio”, red. M. Grabowski, Toruń 1999, s. 61-62. Autor stawia tezę: „[...] można mówić o filozofii chrześcijańskiej tylko i wyłącznie w znaczeniu kontekstu odkrycia. Nie ma „chrześcijańskich” metod filozofowania. Filozofia jest albo dobra, albo zła, albo potrafi przedstawić rzetelne argumenty na uzasadnienie swoich tez, albo nie potrafi. I nic nie pomoże" (s. 62).

${ }^{22}$ Por. M. Blondel, Filozoficzne wyzwanie chrześcijaństwa, tłum. J. Fenrychowa, Kraków 1994. 
komplementarności? Czy rozróżnienie jest tu w ogóle ostre i da się w jakikolwiek sposób zoperacjonalizować? Niech te pytania wyznaczą kolejne szlaki podjętej tu refleksji.

Jan Paweł II w encyklice Fides et ratio podkreśla, że Kościół nie opowiada się za żadną filozofią, nie posiada swej własnej filozofii (eliminuje tym samym sensy 3 i 7, a więc to, co nazwaliśmy „filozofią katolicką”). Przyjmuje też szerokie rozumienie filozofii chrześcijańskiej, która ma oznaczać: „chrześcijańską refleksję filozoficzną, spekulację filozoficzną powstałą w żywotnym związku $\mathrm{z}$ wiarą. Nie określa zatem wyłącznie filozofii wypracowanej przez filozofów chrześcijańskich, którzy w swoich poszukiwaniach nie chcieli zaprzeczać wierze. Mówiąc o filozofii chrześcijańskiej, mamy na myśli wszystkie ważne kierunki myśli filozoficznej, które nie powstałyby bez bezpośredniego lub pośredniego wkładu wiary chrześcijańskiej" (nr 76) ${ }^{23}$. Papież zdaje się więc w zacytowanych słowach przyjmować określenie bliskie sensowi 6, wskazując jako na proprium filozofii chrześcijańskiej nie tylko bezpośredni, ale i pośredni wkład chrześcijaństwa w powstanie określonej filozofii.

Inspiracje ze strony chrześcijaństwa mogą być bezpośrednie, gdy filozof świadomie korzysta z prawd głoszonych w ramach tej religii, lub pośrednie, gdy nieświadomie korzysta z pewnych ustaleń czy pojęć wypracowanych w ramach dyskursów religijnych lub teologicznych. Inspiracje mogą stanowić normę pozytywną, gdy podsuwają refleksji filozoficznej pewne tematy czy problemy lub mogą stanowić normę negatywną, gdy każą odrzucać pewne rozwiązania lub nawet nie stawiać określonych zagadnień. Wydaje się, że tym, co wiąże filozofię z chrześcijaństwem, jest prawda. „Kto szuka prawdy - zauważała Edyta Stein - szuka Boga, choćby o tym nie wiedział". O ile filozofia uprawiana przez niechrześcijan będzie szukała prawdy w przestrzeniach odkrywanych przez rozum, choć - trzeba to mocno podkreślić - nie bez inspiracji „zewnętrznych” tak religijnych, jak i pozareligijnych, by przywołać tu tylko wpływ poezji na kształt myśli filozoficznej Heideggera, o tyle chrześcijanin będzie miał przekonanie płynące $\mathrm{z}$ wiary, że również objawienie religijne

${ }^{23}$ Encyklika Ojca Świętego Jana Pawła II „Fides et ratio”, Kraków 1999, s. 94. 
jest nośnikiem prawdy i będzie czerpał z tych przestrzeni bezpośrednie inspiracje, co oczywiście nie zwalnia go od ich racjonalnego uzasadnienia. Można wszak zapytać, dlaczego czyjeś inspiracje filozoficzne literaturą czy sztuką są dopuszczalne z racjonalistycznego punktu widzenia, a już inspiracje płynące $\mathrm{z}$ Biblii czy $\mathrm{z}$ wiary miałyby być $\mathrm{z}$ wymogami tejże racjonalności sprzeczne. Takie postawienie sprawy zdaje się wynikać $\mathrm{z}$ ideologicznych presupozycji, a nie $\mathrm{z}$ racjonalnej argumentacji. Trzeba pamiętać, że poznanie z wiary daje „ciemne światło” (Stein), które jednak może okazać się niezwykle ważne dla filozoficznego poszukiwania prawdy. Charakter owego „ciemnego światła” poniekąd oczekuje rozjaśnienia na drodze analizy filozoficznej - oto jedno z zadań filozofii chrześcijańskiej. Drogi do prawdy dla filozofa chrześcijanina będą najczęściej sformatowane zarówno przez inspiracje pozytywne, jak i negatywne, a wynikać to będzie z wiary w ich metafilozoficzną wagę i pewność, płynącą z wiary. Zresztą w każdym typie filozofii będą występowały jakieś filtry i przed-założenia („koło hermeneutyczne”), nie zawsze eksplikowane i uświadamiane sobie przez myślicieli ${ }^{24}$.

Duch religii i filozofii jest odmienny, czasem obcy sobie (np. rytualizm religii czy przyjmowanie epistemicznego autorytetu instytucjonalnego), natomiast nadrzędność aksjologiczna prawdy zdaje się łączyć obie dziedziny ludzkiego ducha. Nie znaczy to, że w idei filozofii chrześcijańskiej następuje zlanie się obu paradygmatów, lecz wyłącznie to, że nie stanowią one dwóch osobnych światów. Połączone przez prawdę potrafią wchodzić ze sobą w twórcze relacje, a dzieje kształtowania się doktryny chrześcijańskiej w łączności z filozofią z jednej strony i oddziaływanie chrystianizmu na filozofię z drugiej dostarczają tu wiele interesujących przykładów. Słusznie zauważa Antoni Siemianowski: „Sama zaś filozofia, choć początek jej dali poganie, nie jest żadną miarą

24 Karol Tarnowski mówi o inspiracji akceptowanej żywej (przykładem filozofia średniowieczna), „wziętej w nawias” (przykładem neoscholastyka) oraz inspiracji martwej (wiele zjawisk w filozofii nowożytnej i współczesnej). Por. K. Tarnowski, Człowiek i Transcendencja, Kraków 1995, s. 249. Dziewiętnastowieczny historyk filozofii, Z. Gonzales rozróżniał pomiędzy filozofią z istoty chrześcijańską i filozofią przypadkowo chrześcijańską - ta druga to ta, która w jakikolwiek sposób uległa wpływowi chrystianizmu. Por. E. Gilson, Duch filozofii.., dz. cyt., s. 416. 
dziełem tylko pogańskim, jest dziełem ludzkim. Człowiek w filozofii poszukuje prawdy i kocha to poszukiwanie jako mądrość. Dlatego też chrześcijanin wobec tak ludzkiego trudu, jakim jest filozofia nastawiona na poszukiwanie prawdy, i na miłość mądrości nie może być obojętny. Nie może lekceważyć myślenia poszukującego prawdy"25.

Czy jednak w każdym wypadku filozofia uprawiana przez chrześcijan będzie filozofią chrześcijańską? Czy nie może być po prostu czystą filozofią, jak chce cytowany wyżej Siemianowski ${ }^{26}$ Wydaje się, że filozof chrześcijanin może filozofować, neutralizując inspiracje pozytywne, natomiast negatywne musi raczej brać pod uwagę, co powoduje, że dla wielu myślicieli współczesnych filozofia chrześcijańska jest sprzecznością samą w sobie, owym „drewnianym żelazem” czy „kwadratowym kołem". Możliwe jest wszak takie uprawianie filozofii przez chrześcijan, które jest zamknięte na inspiracje pozytywne, choć $\mathrm{z}$ drugiej strony trzeba przyjąć, że Ewangelia rzuca „metafizyczne światła” na życie i sens życia człowieka, których trudno nie brać pod uwagę, niezależnie od stosunku do tych „rozświetleń”. Osobna kwestia to pytanie, na ile szeroko rozumiane doświadczenie świata, życia, istnienia jest sprzężone z chrześcijańską wizją świata i czy można w ogóle rozplątać nici „czystego” doświadczenia z jego hermeneutycznymi przed-założeniami. Z kolei dla bycia chrześcijaninem myślenie o tym, co pierwsze, o sensie, o arche i wreszcie o samej wierze zdaje się być potrzebą intelektualną i duchową, wynikającą z bycia człowiekiem. Tak więc w porządku subiektywnym filozof chrześcijański to ktoś, kto respektuje inspirację pozytywną i/lub negatywną, a filozof chrześcijanin to ktoś respektujący przynajmniej zasadę negatywną. W porządku obiektywnym filozofią chrześcijańską jest filozofia uprawiana przez filozofów (niekoniecznie chrześcijan) respektujących obie (w sensie szerokim: przynajmniej jedną) zasady.

Filozofią chrześcijańską sensu stricto możemy w świetle powyższych uwag nazwać taki typ filozofii, w której do głosu dochodzi afirmatywne 
podejście do dziedzictwa myślowego, intelektualnego chrześcijaństwa. Dzięki takiej postawie filozof może otwierać się w sensie pozytywnym oraz bezpośrednim na tradycję teologiczną, religijną i podążać w swym poszukiwaniu prawdy w kierunku wskazywanym przez metafizyczne światło niesione przez chrześcijaństwo (w kontekście odkrycia). Stanowi ono dla niego także normę negatywną, każącą odrzucać rozwiązania radykalnie sprzeczne z duchem prawdy niesionej przez chrystianizm. Natomiast filozofią chrześcijańską sensu largo jest filozofia dopuszczająca inspiracje pośrednie, partycypująca w kulturze chrześcijańskiej, ustosunkowująca się pozytywnie lub negatywnie do myśli chrześcijańskiej. W tym sensie filozofią chrześcijańską byłaby prawie cała filozofia europejska, począwszy od przełomu starożytności i średniowiecza, poprzez czasy nowożytne aż do współczesności. Takie szerokie rozumienie zdaje się wpisywać w ducha analiz Karla Jaspersa czy Jana Pawła II przedstawionych w Fides et ratio.

Dobrą ilustracją powyższych propozycji byłaby analiza istnienia i natury etyki chrześcijańskiej. Pytania o jej charakter, typ przyjmowanych aksjomatycznie założeń, punkt wyjścia etc. stawiają problem jej filozoficznej i teologicznej natury. Osmoza świata czystego rozumu i danych płynących z Objawienia zdaje się w przypadku etyki chrześcijańskiej nabierać specyficznego charakteru. Trudno zaprzeczyć istnieniu etyki chrześcijańskiej rozumianej jako filozofia moralna, a z drugiej strony niełatwo byłoby zbudować z niej gmach etyki niezależnej od religii. Spór wokół charakteru etyki św. Tomasza, gdzie jedni opowiadają się za jej niezależnym charakterem opartym na idei prawa naturalnego (Ralph McInery czy Tadeusz Styczeń), a inni twierdzą, że niezbywalne dane płynące z Biblii uniemożliwiają jej autonomiczne traktowanie (Gilson, Maritain), jest świetną ilustracją tego problemu. Nie ma tu, niestety, miejsca na jego szerszą eksplikację.

\section{Przyszłość filozofii chrześcijańskiej}

W dwudziestowiecznej europejskiej myśli filozoficznej uwyraźnił się renesans zainteresowania wiarą i religią (judaizmem i chrześcijaństwem), przełamując oświeceniowy chłód, obojętność, a nierzadko wrogość. Jest to widoczne tak w przestrzeni przedmiotowej - charakter samych 
dyskursów filozoficznych, jak i podmiotowej - postawie życiowej myślicieli. Fenomenologia okazała się dla wielu drogą do wiary (Edmund Husserl, Adolf Reinach, Max Scheler, Edyta Stein, Dietrich von Hildebrand), a jej narzędzia nierzadko służą myślicielom chrześcijańskim nie tylko na gruncie filozofii, ale i teologii. Współczesnym tego przykładem jest choćby książka Roberta Sokolowskiego pt. Obecność eucharystyczna. Studium z teologii fenomenologicznej ${ }^{27}$. Zresztą ciążenie ku religii prawie całej fenomenologii francuskiej zdaje się potwierdzać powyższą tezę. Hermeneutyka, z kolei, powstała z gruntu chrześcijańskiego, mianowicie ze sztuki interpretacji tekstu biblijnego, ze zmagań $\mathrm{z}$ trudnościami interpretacyjnymi tegoż tekstu. Z drugiej strony, jako dojrzały kierunek filozoficzny służyła i służy myśli religijnej, teologii, by wspomnieć Rudolfa Bultmanna czy Karla Rahnera. Wyraźnie ujawnia się tu struktura sprzężenia zwrotnego. Poza tym trzeba zwrócić uwagę na zainteresowanie wątkami religijnymi u wielu przedstawicieli współczesnej hermeneutyki od Paula Ricoeura począwszy, a na Giannim Vattimo skończywszy. $\mathrm{Z}$ ducha chrześcijańskiego zrodził się i nadal twórczo rozwija personalizm. Od wątków religijnych nie stroni egzystencjalizm (w sensie negatywnym byłby tu przykładem Jean Paul Sartre, a w pozytywnym Gabriel Marcel), filozofia analityczna (John Hick, Alvin Plantinga czy Richard Swinburne to tylko trzy z wielu przykładów), nurty pozytywizujące (Michał Heller; warto zresztą zauważyć chrześcijańskie - zdaniem historyków nauki - podłoże umożliwiające powstanie nowożytnego przyrodoznawstwa), filozofia procesu, a nawet postmodernizm. Przykład tego ostatniego pokazuje, że chrystianizm stanowi kontekst filozofii europejskiej, jest jej niezbywalną daną. Seminarium na Capri poświęcone religii z udziałem m.in. postmodernistów zdaje się wpisywać w powyższe konstatacje. Dekonstrukcjonizm Jacques'a Derridy, często przedstawiany jako krańcowo antychrześcijańska filozofia, wyrasta z ducha teologii apofatycznej, negatywnej, która też posługiwała się rozmaitymi technikami dekonstrukcji obrazów Boga, by dojść do przekonania o Jego radykalnej inności, a tym samym niepoznawalności i niewyrażalności.

27 W języku polskim ukazała się w przekładzie zbiorowym w Tarnowie w 1995 roku. 
Heidegger uważał, że chrześcijanin nie może filozofować, bo radykalne pytanie filozofii, dlaczego jest raczej byt niż nic (sformułowane w swej klasycznej postaci przez Leibniza) w świetle wiary chrześcijan jest głupstwem. Można zatem powiedzieć, że jego zdaniem chrześcijaństwo udziela gotowych, zdogmatyzowanych odpowiedzi na podstawowe pytania filozofii, uniemożliwiając dalsze zapytywanie, trwanie w pytaniu jako postawie filozoficznej pobożności. Czy jednak rzeczywiście tak jest? Pyta Joseph Ratzinger: „Ale czy rzeczywiście chrześcijańskie odpowiedzi są tego rodzaju, że zamykają drogę myśleniu? Czy odpowiedzi dotyczące rzeczy ostatecznych nie są ze swej natury zawsze otwarte ku temu, co Niewypowiedziane, a także Niewypowiadalne? Czy nie mogłoby być tak, że właściwie dopiero takie odpowiedzi dają pytaniom ich prawdziwą głębię i dramatyzm? Czy nie mogłoby być tak, że radykalizują one zarówno myślenie, jak i pytanie, wskazując drogę, zamiast blokować?"28 Wydaje się, że w postawionych kwestiach została udzielona odpowiedź na zastrzeżenia Heideggera. Refleksja filozoficzna chrześcijanina jest możliwa, gdyż odpowiedzi, jakie posiada on z racji swej wiary, nie mają charakteru stricte filozoficznego, rozświetlają jedynie horyzont zapytywania filozoficznego, inspirując myślenie, nie blokując jego możliwości. Krytyczna rozmowa $\mathrm{z}$ wielką tradycją religijną zdaje się wszak określać filozofowanie w Europie począwszy od Platona ${ }^{29}$. Dlaczego pojawienie się chrześcijaństwa miałoby ten stan zmienić? Należy pamiętać, że chrześcijańska „wiara słyszy odpowiedź, bo podtrzymuje pytanie" ${ }^{30}$. Rację ma Heidegger wyłącznie w odniesieniu do gnostyckiej wersji chrześcijaństwa. Gnoza wyrażała głębsze ambicje poznawcze niż filozofia - jawiła się jako pewny system wiedzy, dzięki któremu można panować nad rzeczywistością. „Gnoza staje się negacją filozofii, podczas gdy wiara broni wielkości i równocześnie pokory filozofii” ${ }^{31}$.

28 J. Ratzinger, Wiara, filozofia, teologia, [w:] tenże, Prawda w teologii, tłum. M. Mijalska, Kraków 2005, s. 17.

29 Por. tamże, s. 19-20.

30 Tamże, s. 24.

31 Tamże, s. 30. 
Pytając o przyszłość filozofii chrześcijańskiej, trzeba przede wszystkim podjąć wysiłek objaśnienia, co rozumiemy poprzez filozofię chrześcijańską, a tym samym uzmysłowić sobie, o co pytamy. Rozmaitość jej rozumień rodzi u wielu obawy, co do tożsamości filozofii chrześcijańskiej. Jak widzieliśmy, funkcjonuje ona polimorficznie, co razi zwolenników jednej filozofii Kościoła, jaką przez długi czas był tomizm. Zdaje się jednak, że pluralizacja myśli chrześcijańskiej będzie postępowała - w teologii, a tym bardziej w filozofii chrześcijańskiej, i to nie tylko rozumianej sensu largo, ale i sensu stricto. Rodzący się problem z jej tożsamością będzie się w takiej perspektywie pogłębiał. Nie należy jednak, jak się wydaje, kreślić jej granic, ulegając pokusie prostego wskazywania, co jest, a co nie jest filozofią chrześcijańską, a raczej posługiwać się szerokim jej rozumieniem, pozwolić myśli chrześcijańskiej przenikać do wszelkich tradycji filozoficznych, lącznie z tymi, które prima vista jawią się jako obce chrześcijaństwu. Pamiętać wszak trzeba o jego uniwersalistycznym charakterze. Należy zgodzić się ze Stefanem Swieżawskim, który widzi chrześcijańskość filozofii w myśli będącej dogłębną kontemplacją rzeczywistości ${ }^{32}$. Zamykanie się w getcie określonej filozofii chrześcijańskiej $i$ budzenie poczucia osaczenia, otoczenia przez wrogie filozofie jest wyjściem najgorszym z możliwych. Nie oznacza to oczywiście, by zadania filozofii chrześcijańskiej w wąskim rozumieniu należało uznawać za mniej ważne lub przestarzałe. Wydaje się jednak, że wątek uniwersalistyczny będzie stawał się najbardziej doniosły. Generalnie można śmiało zastosować parafrazę słów Barbary Skargi wypowiedzianych w odniesieniu do filozofii jako takiej: „O filozofię chrześcijańską bać się nie musimy!”.

32 S. Swieżawski, O roli, jaka chrześcijaństwo wyznacza filozofii, „Znak” 7-8 (1990), s. 20. Zdaniem Swieżawskiego nie istnieje filozofia chrześcijańska, a co najwyżej inspiracje chrześcijańskie w filozofii. Mówienie o filozofii chrześcijańskiej zakłada zacieranie różnicy między poznaniem naturalnym a poznaniem przez wiarę, co jest charakterystyczne dla myślenia gnostyckiego. 